\title{
Additional Records of Tripletail Lobotes surinamensis (Bloch, 1790), from the Eastern Mediterranean
}

\section{Minasidis, V}

http://hdl.handle.net/10026.1/16176

\subsection{7/s41208-020-00244-6}

Thalassas: An International Journal of Marine Sciences

Springer Science and Business Media LLC

All content in PEARL is protected by copyright law. Author manuscripts are made available in accordance with publisher policies. Please cite only the published version using the details provided on the item record or document. In the absence of an open licence (e.g. Creative Commons), permissions for further reuse of content should be sought from the publisher or author. 


\section{Thalassas: An International Journal of Marine Sciences Additional records of Tripletail Lobotes surinamensis (Bloch, 1790), from the eastern Mediterranean --Manuscript Draft--}

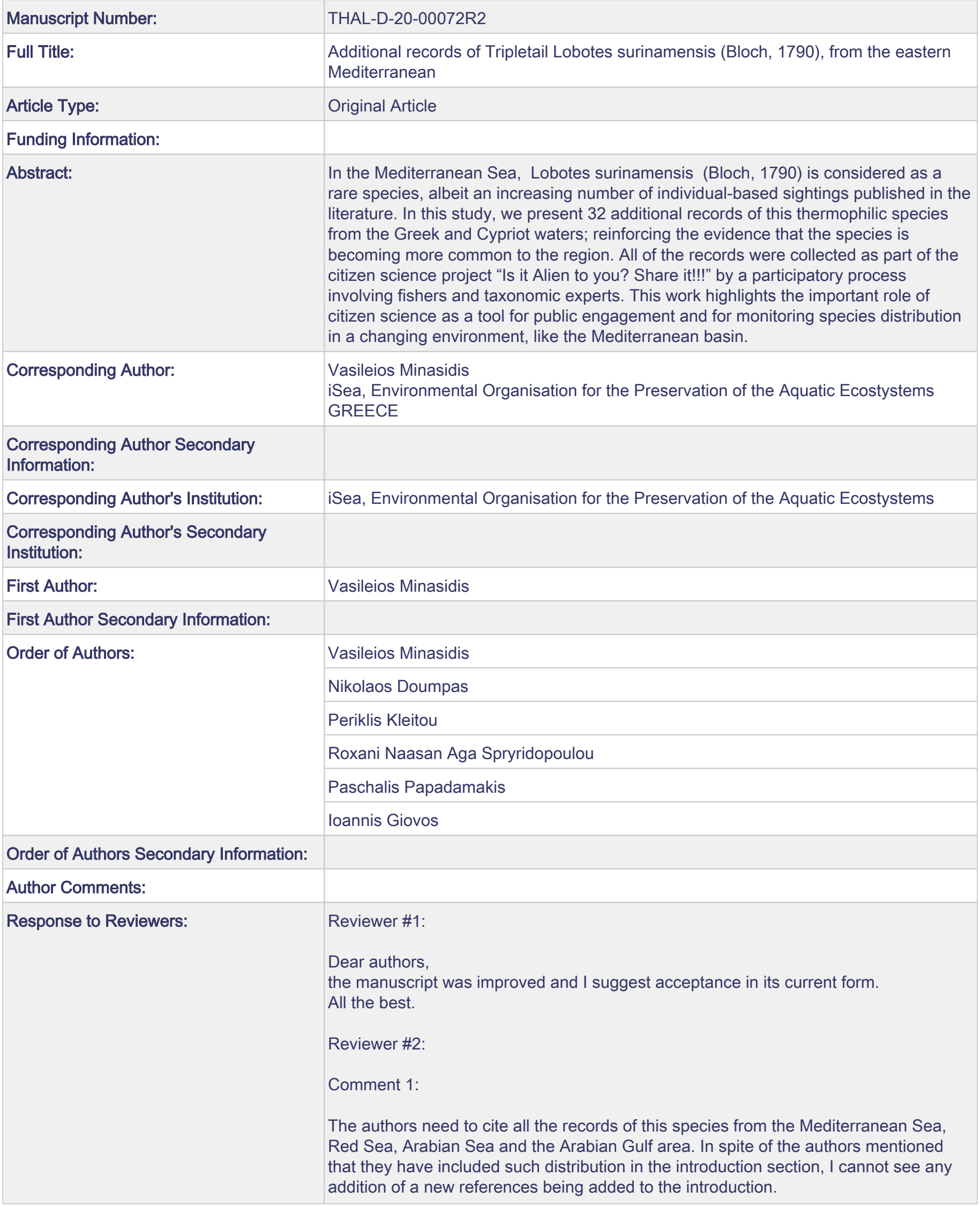


Authors' Response:

The references added

Powered by Editorial Manager ${ }^{\circledR}$ and ProduXion Manager ${ }^{\circledR}$ from Aries Systems Corporation 
Click here to view linked References

\title{
Additional records of Tripletail Lobotes surinamensis (Bloch, 1790), from the eastern Mediterranean
}

\author{
Vasileios Minasidis ${ }^{1 *}$, Nikolaos Doumpas ${ }^{1}$, Periklis Kleitou ${ }^{1,2}$, Roxani Naasan Aga \\ Spryridopoulou $^{1}$, Paschalis Papadamakis ${ }^{3}$, Ioannis Giovos ${ }^{1,2}$ \\ ${ }^{1}$ iSea, Environmental Organisation for the Preservation of the Aquatic Ecosystems, Ochi Av. 11, 55438 \\ Agios Paulos, Thessaloniki, Greece \\ ${ }^{2}$ Marine and Environmental Research (MER) Lab Ltd., 202 Amathountos Av., Marina Gardens, Block B, \\ Offices \#13-14, Parekklisia, 4533 Limassol, Cyprus \\ ${ }^{3}$ Fisheries Research Institute, 64007 Nea Peramos, Kavala, Greece
}

*Corresponding author: vasilis.minasidis@isea.com.gr, +30 2313090696 


\begin{abstract}
In the Mediterranean Sea, Lobotes surinamensis (Bloch, 1790) is considered as a rare species, albeit an increasing number of individual-based sightings published in the literature. In this study, we present 32 additional records of this thermophilic species from the Greek and Cypriot waters; reinforcing the evidence that the species is becoming more common to the region. All of the records were collected as part of the citizen science project "Is it Alien to you? Share it!!!" by a participatory process involving fishers and taxonomic experts. This work highlights the important role of citizen science as a tool for public engagement and for monitoring species distribution in a changing environment, like the Mediterranean basin.
\end{abstract}

\title{
Keywords: Lobotidae, Eastern Mediterranean Sea, Citizen science, Monitoring, Rare species
}

\section{Introduction}

The Atlantic tripletail or tripletail, Lobotes surinamensis (Bloch, 1790), is a marine species found in tropical and subtropical waters of all oceans; in the western Atlantic from New England southward to Argentina (Carpenter 2003) and Falkland Islands (Carpenter and Robertson 2015), in the eastern Atlantic from the Straits of Gibraltar to the Gulf of Guinea and Madeira (Carpenter and Johnson 2016), in the IndoPacific from East Africa through all countries of Southeast Asia north to Taiwan Province of China and southern Japan, northern Australia to southern Queensland, New Guinea to New Britain, and south to Fiji, except eastern Pacific (Florida Museum of Natural History 2005). It is a demersal and thermophilic species (Riede 2004) that lives at depths from 0 to 70 meters (Fricke et al. 2011), usually shallower than 10 meters, and with preference to brackish waters (Myers 1999; Kuiter and Tonozuka 2001). The maximum length reported is $110 \mathrm{~cm}$ (Robins and Ray 1986), normally ranging between 40 and $80 \mathrm{~cm}$ (Bouhlel 1988). The color of the fish is green-grey, darker in the top and lighter in the belly, with yellowish shades all over the body (Heemstra 1986). Juveniles are mottled with yellowish, brownish and black blotches, while adults can show a more uniform color, dark brown, greyish or blackish. Its common name "tripletail" comes from the dorsal and anal fins, that are more flattened, looking like extra tails (Smith 1997). L. surinamensis is often found swimming near the surface alone or in very small schools of two to four individuals (Breder 1949). 
The species exhibits a well-known plant-mimetic behavior; swimming side by side with floating objects as a survival strategy to attract unsuspicious prey, avoid predators, and probably benefit from drifting long distances (Breder 1949; Watson 1996; Massuti and Renores 1994).

Lobotes surinamensis distribution has been geographically expanded from the Atlantic Ocean into the Mediterranean Sea via the Strait of Gibraltar (Deidun et al. 2010). In the Mediterranean Sea, the species was first recorded in 1875 (Doderlein 1875). Since then, L. surinamensis individuals have been reported across the entire region (Palom 1991; Gücü and Bingel 1994; De Pirro et al. 1996; Riera et al. 1999; Hemida et al. 2003; Camilleri et al., 2005; Zava et al. 2007; Deidun et al., 2010; Dulčić and Dragičević 2011;Tiralongo et al., 2016; Tunçer and Önal 2016; Tiralongo et al. 2018; Azzurro et al., 2019; Elbaraasi et al., 2019; Licchelli and Denitto, 2020). In Greece, the first documented report of the species dates back in 1968 (Aegean Sea) (Bini 1968). Since then, few record have been reported from the Greek seas (Ondrias 1971; Roux in Whitehead et al. 1986; Fischer et al. 1987; Papaconstantinou 1988; Koutsogiannopoulos 2010), including the Aegean Sea (Economidis 1973; Economidis and Bauchot 1976) and sporadically other areas, such as Thermaikos Gulf (Minos and Economidis 2007) and Maliakos Gulf (Kavadas and Bekas 2014). In Cyprus, L. surinamensis was first sighted in 2008 (Coral Bay, Paphos) and subsequently reported from Limassol in 2015 (34³3'58.1"N, 3301'05.1"E), and from Paphos, Peyia - Coral bay port (3451'22.0"N, 32²1'41.6"E), in 2016 (Dulčić et al. 2014; Kleitou and Crocetta 2016).

In this work, we utilized citizen science and social media to collect observations of tripletail from the Greek and Cypriot marine waters (eastern Mediterranean) providing additional information on basic ecological information of the species. Citizen science is currently emerging globally, empowering scientists by providing massive and spatially broad data (Newman et al. 2012). The method is currently flourishing in the Mediterranean, highly supported by the increasing use of social media and other modern technologies like smartphones (Cardoso et al. 2017). Several projects exist that facilitate massive reporting of various marine taxa (Giovos et al. 2019 and references within; Tiralongo et al., 2019a; Bargnesi et al. 2020 and references within; Naasan Aga Spyridopoulou et al. 2020) and habitats (Gerovasileiou et al. 2016). Our data highlight the value of citizen science and social media for supporting marine research in the changing environment of the Mediterranean Sea. 


\section{Materials and Methods}

In 2016, an online data repository was established by iSea, in which citizen scientists could easily upload photographic material along with information on specimen size (length and/or weight), depth, number of specimens, exact location, date, type of observation (freediving, underwater photography, shore-base fishing, boat-based fishing, spearfishing), substrate (seagrass, rocky substrate, soft substrate) and the adeptness of the reporter (recreational fisher, photographer, naturalist, etc). All pictures are checked for their authenticity and originality using the automatic image recognition tool of Google. All verified pictures are sent to a team of taxonomic experts that identifies the species to the lowest taxonomic level possible and validates the observations before a record is uploaded in the project's database (see Giovos et al. 2019).

A group on Facebook was established back in 2017 to facilitate citizen science. The project's Facebook group currently numbers more than 11,500 members, with about 5,000 actively engaged on a daily basis. The vast majority of the participants are recreational fishers, followed by scuba divers, naturalists and professional fishers (Giovos et al. 2019). Furthermore, the group community includes several experts on marine alien species offering their expertise for the identification of the reported specimens while at the same time influence and engaging public engagement with scientific issues.

\section{Results and Discussion}

In total, 27 observations of the species were collected in the context of this work between 2007-2019. Specifically, 9 observations were recorded from Cyprus and 18 from Greece (Table 1; Fig. 1). From those observations, 32 individuals were reported. The majority of the observers were recreational fishers (45.00\%), followed by scientists (22.00\%), free divers (11.00\%) and others (e.g. beachgoers, journalists and news reporters) while most records were reported in 2018 (Table 1). About 19\% of the records were found in brackish waters (number 4, 5, 16, 24, 25 in Table 1). Interestingly, several records were juvenile individuals exhibiting various coloration patterns.

The present work provides additional information for one uncommon species of fish in the Mediterranean Sea. To date, the citizen science project of iSea "Is it Alien to you? Share it !!!" has gathered a vast amount of information, including several records of alien and rare species from the eastern Mediterranean (Giovos 
et al. 2019; Naasan Aga Spyridopoulou et al. 2020) and first records of alien and native species from the Mediterranean (e.g. Giovos et al. 2018; Langeneck et al. 2019; Giovos et al. 2020), Greece (e.g. Tiralongo et al. 2019b; Tsiamis and Giovos 2019) and Cyprus (e.g. Doumpas and Kleitou 2019; Kleitou et al. 2019).

Our data suggest that L. surinamensis might be more frequent than previously thought (Coll et al. 2010 estimated the mean probability of L. surinamensis occurrence 0.36 , with 0.40 being the threshold for frequent species) at least in the waters of Greece and Cyprus. The species is thermophilic and originally was more abundant in the South and East Mediterranean (Akyol and Kara 2012; Bilge et al. 2016). Several native species in the Mediterranean are currently displaying a northward expansion like Sparisoma cretense (Linnaeus, 1758) (Kruschel et al. 2012) or Alectis alexandrina (Geoffroy Saint-Hilaire, 1817) (Naasan Aga Spyridopoulou et al. 2020) as a result of the increasing sea surface temperatures (Volosciuk et al. 2016; Pastor et al., 2018). It could be the case that the species is favored by the climate change as predicted for thermophilic species in general (Moullec et al. 2019; Dimitriadis et al. 2020). Interestingly, almost half of the observations $(48.00 \%)$ were reported inside ports/harbors, while approximately $19 \%$ of records were observed close to estuaries and brackish waters, such as the Evros River, the Strymonas River and the Lissos River (Fig. 1; Table 1), indicating a preference of the species for protected, unexposed habitats . Furthermore, most of the records were found in shallow waters below 10 meters depth (Table 1). It is possible that the increasing number of the species records might be a result of the increasing number of citizen science projects in the Mediterranean and the use of social media (Giovos et al., 2019 and all references within).

The contribution of citizen science is becoming crucial in marine science nowadays. The proper communication with scientists is constantly producing new data that can be used to understand the presence and distribution of species in the Mediterranean Sea. Citizen science has the potential to address a big gap in marine research despite a margin of error that should be taken into account since reports are provided by non-scientists (Marshall and Pierce 2012; Katsanevakis and Moustakas 2018; Naasan Aga Spyridopoulou et al. 2020). In a shifting climate and a changing basin, the participation and contribution of citizen scientists in monitoring shifts in species distributions is critical (Giovos et al., 2019; Azzuro et al., 2019). 
Scientists in the Mediterranean must continue monitoring the presence of the species to confirm or reject the hypothesis of its fast range expansion due to the increasing sea surface temperatures in the basin.

\section{Acknowledgements}

We would like to express our gratitude to the recreational fishers George Aristidou, George Boukis, Elias Karach, Yiannis Karavas, Elias Koutsoukanidis, Christos Tsoupas and Stelios Zafeirelis for sharing their data and pictures from Greece; Dimitris Georgiou, Christoforos Panagi, Andreas Stavrou and Paris Tkdf for Cyprus specimens. We are also grateful to researcher Aris Christidis as well as photographers Giorgos Poulios (Greece) and Matt Smith (Cyprus) for sharing photographic evidence and pieces of information.

\section{References}

Akyol O, Kara A (2012) Record of the Atlantic tripletail, Lobotes surinamensis (Bloch, 1790) in the Bay of Izmir, northern Aegean Sea. J Appl Ichthyol 28:645-646

Azzurro E, Bariche M, Bolognini L, Cerri J, Gianni F, Sbragaglia V, Souissi JB (2019) Climate change, biological invasions, and the shifting distribution of Mediterranean fishes: A large-scale survey based on local ecological knowledge. Global Change Biology. https://doi.org/10.31230/osf.io/zgupd

Bargnesi F, Ferretti F, Lucrezi S (2019) Opportunities from citizen science for shark conservation, with a focus on the Mediterranean Sea. Eur Zool J 87(1):20-34

Bettoso N, Comisso G, Kruzic P (2016) First Record of the Tripletail Lobotes surinamensis (Pisces: Lobotidae) in the Lagoon of Marano and Grado (Gulf of Trieste, Northern Adriatic Sea). Annales Series Historia naturalis 26:209212

Bilge G, Filiz H, Gülşahin A (2016) Occurrence of Lobotes surinamensis (Osteichthyes: Lobotidae) in the Mediterranean: Historical and recent data. Zoology in the Middle East. https://doi.org/10.1080/09397140.2017.1269392 
Bini G (1968) Un pesce perciforme raro per i mari Italiani "Lobotes surinamensis, (Bloch 1790)". Atti della Accademia Peloritana dei Pericolanti Classe di Scienze Fisiche, Matematiche e Naturali 14(1/2):3-7

Bouhlel M (1988) Poissons de Djibouti. Placerville (California, USA): RDA International, Inc p 416 Breder Jr CM (1949) "On the Behavior of Young Lobotes surinamensis". Copeia(4):237-242

Camilleri M, Ragonese S, Darmanin M, Rosso B (2005) The discovery of a specimen of Lobotes surinamensis off the Maltese Islands (central Mediterranean Sea). Biologia Marina Mediterranea 12:480-483

Cardoso A, Adriaens T, Copas K, Flevaris S, Galiay P, Gervasini E, Jennings E, Josefsson M, López B, Magan J, Marchante E, Montani E, Quintas M, Roy H, Schade S, See L, Tsiamis K, Taucer F, von Schomberg R (2017) Citizen Science and Open Data: a model for Invasive Alien Species in Europe. Research Ideas and Outcomes. https://doi.org/10.3897/rio.3.e14811

Carpenter KE (2003) Lobotidae. Tripletails. In Carpenter K.E. (ed) The living marine resources of the Western Central Atlantic, Vol 3: Bony fishes part 2 (Opistognathidae to Molidae), sea turtles and marine mammals. FAO species identification guide for fishery purposes, p 1505

Carpenter KE, Robertson R (2015) Lobotes surinamensis. The IUCN Red List of Threatened Species 2015: e.T198670A16644032. http://dx.doi.org/10.2305/IUCN.UK.2015-4.RLTS.T198670A16644032.en

Carpenter KE, Johnson GD (2016) Lobotidae. Tripletails. In K.E. Carpenter and N. De Angelis (eds) The living marine resources of the Eastern Central Atlantic. Vol 4: Bony fishes part 2 (Perciformes to Tetradontiformes) and Sea turtles. FAO Species Identification Guide for Fishery Purposes, Rome, FAO, p 2544

Dimitriadis C, Azzurro E, Castriota L, Corsini-Foka M, Falautano M, Fournari-Konstantinidou I, Galanidi M, Giovos I, Issaris Y, Kalimeris A, Karachle P, Katsanevakis S, Kytinou E, Zenetos A (2020) Updating the occurrences of Pterois miles in the Mediterranean Sea, with considerations on thermal boundaries and future range expansion. Mediterranean Marine Science 21(1):62-69. https://doi.org/10.12681/mms.2184

De Pirro M, Tosi G, Vanni S (1996) Terza catturanei mari italiani di Lobotes surinamensis (Bloch, 1790) (Actinopterygii, Perciformes, Lobotidae). Atti della Societa Toscana de Scienze Naturali di Pisa, Serie B 103:113-114

Deidun A, Sammut R, Sciberras A, Vella P (2010) On the increasing occurrence of Lobotes surinamensis in Maltese coastal waters. Aquatic Invasions 5(Supp 1):S113-S116

Doderlein P (1875) Descrizione di una specie delgenere esotico Lobotes, presa nelle acque dei contornidi Palermo. Memoria del socio Prof. Pietro Doderlein Palermo Tipografi a Fraurentenfelder, pp 13 
Dulčić J, Dragičević B (2011) First record of the Atlantic tripletail, Lobotes surinamensis (Bloch, 1790), in the Adriatic Sea. J Appl Ichthyol 27:1385-1386

Dulčić J, Dragičević B, Lipej L, Štifanić M (2014) Range extension of tripletail Lobotes surinamensis (Lobotidae) in the Adriatic Sea. A northernmost record in the Mediterranean. Cybium 38:153-154

Economidis PS (1973) Cataloque de Poisons de la Grèce. Hellenic Oceanology and Limnology 11:421-598

Economidis PS, Bauchot ML (1976) Sur une collection de poissons des mers hélleniques (mers Égée et lonienne) déposée au Muséum national d' histoire naturelle. Bulletin du Museum National d'Histoire Naturelle. 3e Serie. Zoologie, Paris, 3e ser., No 392, Zool 274:871-903

Elbaraasi H, Azzurro E, Bashir A, Elaabidi S, Elabar B, Elsilini O, Shakman E (2019) Updated checklist of bony fishes along the Libyan coasts (Southern Mediterranean Sea). Mediterranean Marine Science 20(1):90-105. https://doi.org/10.12681/mms.15570

Fischer W, Bauchot ML, Schneider MS (1987) Fishes FAO d' identification des espèces pour les besoins de la Pêche (Revision 1). Zone de pêche 37. Vol 2, Vertébrés. FAO et CEE Publishers, Rome, pp 761- 1530

Florida Museum of Natural History (2005) Biological profiles: tripletail. Retrieved on 26 August 2005, from www.flmnh.ufl.edu/fish/Gallery/Descript/Tripletail/Tripletail.html. Ichthyology at the Florida Museum of Natural History: Education-Biological Profiles. FLMNH, University of Florida.

Fricke R, Kulbicki M, Wantiez L (2011) Checklist of the fishes of New Caledonia, and their distribution in the Southwest Pacific Ocean (Pisces). Stuttgarter Beiträge zur Naturkunde A, Neue Serie 4:341-463

Gerovasileiou V, Arvanitidis C, Dailianis T, Dimitriadis C, Doğan A, Filiopoulou I, Gatti G, Issaris Y, Jean-Pierre F, Koutsoubas D, Laure Thierry de Ville d'Avray, Melih Ertan Ç, Michalakis N, Panteri E, Romain D, Salomidi M, Sini M (2016) CIGESMED for divers: Establishing a citizen science initiative for the mapping and monitoring of coralligenous assemblages in the Mediterranean Sea. Biodiversity Data Journal 4:1-23. https://doi.org/10.3897/BDJ.4.e8692

Giovos I, Crocetta F, Doumpas N, Kaminas A, Kleitou P, Langeneck J, Tiralongo F (2020) First record of the Atlantic spadefish Chaetodipterus faber (Broussonet, 1782) in the Mediterranean Sea: is it a new aquarium release? Biolnvasions Records 9(1):89-95

Giovos I, Bernardi G, Kleitou P, Marmara D, Romanidis-Kyriakidis G (2018) First records of the fish Abudefduf sexfasciatus (Lacepède, 1801) and Acanthurus sohal (Forsskål, 1775) in the Mediterranean Sea. Biolnvasions Records 7(2):205-210 
Giovos I, Batjakas I, Bernardi G, Crocetta F, Doumpas N, Kalogirou S, Kampouris T, Katsanevakis S, Keramidas I, Kleitou P, Langeneck J, Maximiadi M, Mitsou E, Poursanidis D, Romanidis-Kyriakidis G, Stoilas VO, Tiralongo F, Xentidis $\mathrm{N}$, Zenetos A (2019) Citizen-science for monitoring marine invasions and stimulating public engagement: a case project from the eastern Mediterranean. Biolnvasions Records 21:3707-3721

Gücü AC, Bingel F (1994) Trawlable species assemblages on the continental shelf of the northeastern Levant Sea (Mediterranean) with an emphasis on Lessepsian migration. Acta Adriat 35:83-100 Heemstra PC (1986) Smiths' sea fishes. In M.M. Smith and P.C. Heemstra (eds) Lobotidae. Springer-Verlag, Berlin, pp $621-622$

Hemida F, Capape C, Diatta Y, Golani D (2003) On the occurrence of tripletail, Lobotes surinamensis (Bloch, 1790) (Osteichthyes: Lobotidae) off the coast of Algeria (southern Mediterranean). Annales Series Historia naturalis $13: 145-148$

Katsanevakis S, Acar Ü, Ammar I, Balci BA, Bekas P et al (2014) New Mediterranean Biodiversity Records (October 2014). Mediterranean Marine Science 15(3):675-695

Katsanevakis S, Moustakas A (2018) Uncertainty in Marine Invasion Science. Front Mar Sci 5:38

Kavadas S, Bekas P (2014) New record of Lobotes surinamensis (Bloch, 1790) from Maliakos Gulf (Central Aegean Sea, Greece). Mediterranean Marine Science 15:691

Kleitou P, Crocetta F (2016) First record of the rare native fish Lobotes surinamensis (Bloch, 1790) in Cyprus. Mediterranean Marine Science 17:813

Kleitou P, Crocetta F, Giovos I, Wolf W (2019) On the importance of citizen-science: the first record of Goniobranchus obsoletus (Rüppell and Leuckart, 1830) from Cyprus (Mollusca: Gastropoda: Nudibranchia). Biolnvasions Records 8(2):252-257

Koutsogiannopoulos DD (2010) The fish of Greece. A complete guide of all fish which leave in Greek seas. Athens, Greece, pp 494

Kruschel C, Dahlke S, Schultz ST, Zubak I, (2012). New records of the parrot fish, Sparisoma cretense, and the cleaver wrasse, Xyrichtys novacula, by visual census in the Southern Adriatic. Annales Series Historia naturalis 22(1):47

Kuiter RH, Tonozuka T (2001) Pictorial guide to Indonesian reef fishes. Part 2. Fusiliers - Dragonets, Caesionidae Callionymidae. Zoonetics, Australia, pp 304-622 
Langeneck J, Boero F, Crocetta F, Doumpas N, Giovos I, Piraino S (2019) First record of the non-native jellyfish Chrysaora cf. achlyos (Cnidaria: Pelagiidae) in the Mediterranean Sea. Biolnvasions Records 8(3):608-613

Licchelli C, Denitto F (2020) First record of Lobotes surinamensis (Bloch, 1790) in the North lonian Sea. Mediterranean Marine Science 21(2):348

Marshall AD, Pierce SJ (2012) The use and abuse of photographic identification in sharks and rays. J Fish Biol 80:13611379

Massuti E, Renones O (1994) Observations on the pelagic fish community around floating objects in the open sea off Mallorca. Bol Inst Esp Oceanogr 10:81-93

Minos G, Economidis PS (2007) On the occurrence of tripletait, Lobotes surinamensis (Bloch, 1790) (Pisces: Lobotidae), in North Aegean Sea (Greece). p. 242. In: 12th European Congress of Ichthyologists. Cavat (Dubrovnik), Croatia, 9-13 September 2007. EIS.

Moullec F, Barrier N, Guilhaumon F, Marsaleix P, Shin YJ, Somot S (2019). An End-to-End model reveals losers and winners in a warming Mediterranean Sea. Frontiers in Marine Science 6:345

Myers RF (1999) Micronesian reef fishes: a comprehensive guide to the coral reef fishes of Micronesia, 3rd revised and expanded edition. Coral Graphics, Barrigada, Guam, pp 330

Naasan Aga Spyridopoulou R, Bouziotis D, Giovos I, Kalogirou S, Kleitou P, Langeneck J (2020) Filling the Gap of DataLimited Fish Species in the Eastern Mediterranean Sea: A Contribution by Citizen Science. J Mar Sci Eng 107(2):107. https://doi.org/10.3390/jmse8020107

Newman G, Crall A, Crowston K, Graham E, Newman S, Wiggins A (2012) The future of citizen science: emerging technologies and shifting paradigms. The Ecological Society of America journals. Frontiers in Ecology and the Environment 10(6):298-304. https://doi.org/10.1890/110294

Ondrias JC (1971) A list of the fresh and sea water fishes of Greece. Hellenic Oceanology and Limnology 10:23-96 Palom O (1991) Primera cita de Lobotes surinamensis (Bloch, 1790) (Pisces, Lobotidae) para la ictiofauna iberica. Miscellania Zoologica 15:240-242

Papaconstantinou C (1988) Check-list of marine fishes of Greece. Fauna Graeciae IV. National Centre Marine Research \& Hellenic Zoological Society Publishers, Athens, pp 257

Pastor F, Valiente JA, Palau JL (2018) Sea Surface Temperature in the Mediterranean: Trends and Spatial Patterns (1982-2016). Pure Appl Geophys 175:4017-4029 
Riede K (2004) Global register of migratory species - from global to regional scales. Final Report of the R\&D-Projekt 80805 081. Federal Agency for Nature Conservation, Bonn, Germany, pp 329

Riera F, Grau A, Grau AM, Pastor E, Pou S, Quetglas A (1999) Ichthyofauna associated with drifting floating objects in the Balearic Islands (western Mediterranean). Sci Mar 63:229-235

Robins CR, Ray GC (1986) A field guide to Atlantic coast fishes of North America. Houghton Mifflin Company, Boston, U.S.A., pp 354

Smith CL (1997) National Audubon Society field guide to tropical marine fishes of the Caribbean, the Gulf of Mexico, Florida, the Bahamas, and Bermuda. Alfred A. Knopf, Inc., New York, pp 720

Tiralongo F (2016) New record of Lobotes surinamensis (Bloch, 1790) from italian waters (Adriatic Sea). In: Dailianis et al. New Mediterranean Marine Biodiversity Records. Mediterranean Marine Science 17(2):608-626

Tiralongo F, Coco S, Lombardo BM, Messina G (2018) On the Presence of a Well-Established Population of Lobotes surinamensis (Bloch, 1790) in the central Mediterranean Sea. Annales Series Historia naturalis 28(1):31-36

Tiralongo F, Lillo AO, Tibullo D, Tondo E, Lo Martire C, D'Agnese R, Macali A, Mancini E, Giovos I, Coco S, Azzurro E (2019a) Monitoring uncommon and non-indigenous fishes in Italian waters: one year of results for the AlienFish project. Regional Studies in Marine Science. https://doi.org/10.1016/j.rsma.2019.100606

Tiralongo F, Crocetta F, Doumpas N, Giovos I, Kleitou P, Langeneck J (2019b) Is the mangrove red snapper Lutjanus argentimaculatus (Forsskål, 1775) established in the eastern Mediterranean Sea? First records from Greece through a citizen science project. Biolnvasions Records 8(4):911-916

Tsiamis K, Giovos I (2018) First record of the green alga Acetabularia caliculus from Greece. Mediterranean Marine Science 19(3):684

Tunçer S, Önal U (2016) The occurrence of the Atlantic Tripletail, Lobotes surinamensis (Bloch, 1790), in the Çanakkale Strait. Mediterranean Marine Science 17(1):247-248

Volosciuk C, Gulev SK, Latif M, Maraun D, Semenov VA, Tilinina N (2016) Rising mediterranean sea surface temperatures amplify extreme summer precipitation in central Europe. Scientific reports 6(1):1-7

Watson W (1996) Lobotidae: tripletails. p. 995-997. In H.G. Moser (ed.) The early stages of fishes in the California Current Region. California Cooperative Oceanic Fisheries Investigations (CalCOFI) Atlas No. 33. Allen Press, Inc., Lawrence, Kansas. 1505 p.

Whitehead PJP, Bauchot ML, Hureau JC, Nielsen J, Tortonese E (1986) Fishes of the North-eastern Atlantic and the Mediterranean. UNESCO (Ed). Vol 2, pp 511-1007; Vol 3, pp 1008-1473 
Zava B, Gianguzza P, Riggio S (2007) New capture of the tripletail Lobotes surinamensis (Bloch, 1790) in the southern Tyrrhenian Sea (Osteichthyes: Lobotidae) (in Italian with English abstract). Biologia Marina Mediterranea $14: 370$ 
Table 1. Records of Lobotes surinamensis in the eastern Mediterranean Sea with information on number of individuals

(N), depth (m), area, coordinates (Latitude: Longitude), date (DD/MM/YYYY), type of observation (T.OB.)

(spearfishing, S; boat fishing, BF; shore fishing, SF; shore photography, SP; recreational longlining, RL; swimming animal, SA; underwater photography, UP; hand gathering, HG; nets, N; land observation, LO) and links of the photographic evidence of each observation.

\begin{tabular}{|c|c|c|c|c|c|c|c|}
\hline $\mathbf{n}$ & $\mathrm{N}$ Individuals & Depth & Area & Coordinates & Date & T.OB. & Links \\
\hline 1 & 1 & 10 & Pirgadikia, Greece & $40^{\circ} 20^{\prime} 04.0^{\prime \prime} \mathrm{N}, 23^{\circ} 43^{\prime} 10.2^{\prime \prime} \mathrm{E}$ & $03 / 07 / 2007$ & $S$ & Photo 1 \\
\hline 2 & 1 & N/A & Lesvos island, Greece & $39^{\circ} 10^{\prime} 04.3^{\prime \prime} \mathrm{N}, 26^{\circ} 09^{\prime} 43.4^{\prime \prime} \mathrm{E}$ & $01 / 07 / 2009$ & $\mathrm{BF}$ & Photo 2 \\
\hline 3 & 1 & N/A & Skopelos island, Greece & $39^{\circ} 07^{\prime} 19.3^{\prime \prime N}, 23^{\circ} 43^{\prime} 44.7^{\prime \prime E}$ & 08/07/2015 & SP & Photo 3 \\
\hline 4 & 1 & 0 & Argolic Gulf, Greece & $37^{\circ} 32^{\prime} 08.2^{\prime \prime} \mathrm{N}, 22^{\circ} 55^{\prime} 07.4^{\prime \prime E}$ & $27 / 04 / 2017$ & $\mathrm{SF}$ & Photo 4 \\
\hline 5 & 1 & 45 & $\begin{array}{l}\text { Strimonikos Gulf, } \\
\text { Greece }\end{array}$ & $40^{\circ} 45^{\prime} 39.3^{\prime \prime} \mathrm{N}, 23^{\circ} 49^{\prime} 42.5^{\prime \prime} \mathrm{E}$ & 03/09/2017 & RL & Photo 5 \\
\hline 6 & 1 & N/A & Skopelos island, Greece & $39^{\circ} 07^{\prime} 23.2^{\prime \prime} \mathrm{N}, 23^{\circ} 43^{\prime} 48.0^{\prime \prime} \mathrm{E}$ & In 2017 & SA & - \\
\hline 7 & 1 & N/A & Allonisos island, Greece & $39^{\circ} 08^{\prime} 39.8^{\prime \prime} \mathrm{N}, 23^{\circ} 51^{\prime} 55.5^{\prime \prime} \mathrm{E}$ & In 2017 & SA & - \\
\hline 8 & 1 & $\mathrm{~N} / \mathrm{A}$ & Lakonikos Gulf, Greece & $36^{\circ} 30^{\prime} 26.2^{\prime \prime} \mathrm{N}, 23^{\circ} 03^{\prime} 28.4^{\prime \prime} \mathrm{E}$ & In 2017 & $\mathrm{SF}$ & - \\
\hline 9 & 1 & 0 & $\begin{array}{l}\text { Chrysochou Gulf, } \\
\text { Cyprus }\end{array}$ & $35^{\circ} 04^{\prime} 16.6^{\prime \prime} \mathrm{N}, 32^{\circ} 20^{\prime} 07.1^{\prime \prime} \mathrm{E}$ & $13 / 10 / 2017$ & UP & Photo 9 \\
\hline 10 & 1 & 0 & Ormos Panagias, Greece & $40^{\circ} 13^{\prime} 57.6^{\prime \prime} \mathrm{N}, 23^{\circ} 44^{\prime} 17.9^{\prime \prime} \mathrm{E}$ & In 2017 & SP & $\underline{\text { Photo } 10}$ \\
\hline 11 & 1 & 0 & Protaras, Cyprus & $35^{\circ} 00^{\prime} 00.6^{\prime \prime} \mathrm{N}, 34^{\circ} 04^{\prime} 06.5^{\prime \prime} \mathrm{E}$ & $24 / 09 / 2017$ & HG & Photo 11 \\
\hline 12 & 1 & 7 & $\begin{array}{l}\text { Chrysochou Gulf, } \\
\text { Cyprus }\end{array}$ & $35^{\circ} 03^{\prime} 08.6^{\prime \prime N}, 32^{\circ} 22^{\prime} 27.9^{\prime \prime} \mathrm{E}$ & $24 / 10 / 2017$ & UP & $\underline{\text { Photo } 12}$ \\
\hline 13 & 1 & 0 & Protaras, Cyprus & $35^{\circ} 03^{\prime} 05.5^{\prime \prime} \mathrm{N}, 34^{\circ} 01^{\prime} 26.3^{\prime \prime} \mathrm{E}$ & $27 / 09 / 2017$ & S & Photo 13 \\
\hline 14 & 1 & 2 & Evoikos Gulf, Greece & $38^{\circ} 20^{\prime} 14.4^{\prime \prime} \mathrm{N}, 23^{\circ} 54^{\prime} 50.4^{\prime \prime} \mathrm{E}$ & $23 / 05 / 2018$ & $\mathrm{SF}$ & Photo 14 \\
\hline 15 & 1 & N/A & Protaras, Cyprus & $35^{\circ} 00^{\prime} 11.5^{\prime \prime} \mathrm{N}, 34^{\circ} 03^{\prime} 50.9^{\prime \prime} \mathrm{E}$ & $12 / 03 / 2018$ & HG & $\underline{\text { Photo } 15}$ \\
\hline 16 & 1 & N/A & Delta Evrou, Greece & $40^{\circ} 48^{\prime} 25.3^{\prime \prime} \mathrm{N}, 26^{\circ} 01^{\prime} 32.3^{\prime \prime} \mathrm{E}$ & 09/07/2018 & $\mathrm{N}$ & $\underline{\text { Photo } 16}$ \\
\hline 17 & 1 & 0 & Cape Greko, Cyprus & $34^{\circ} 59^{\prime} 01.3 " \mathrm{~N}, 34^{\circ} 04^{\prime} 11.9^{\prime \prime} \mathrm{E}$ & $29 / 08 / 2018$ & UP & - \\
\hline 18 & 2 & N/A & Skopelos island, Greece & $39^{\circ} 07^{\prime} 26.0^{\prime \prime} \mathrm{N}, 23^{\circ} 43^{\prime} 49.9^{\prime \prime} \mathrm{E}$ & $09 / 09 / 2018$ & SA & Photo 18 \\
\hline 19 & 2 & 0.1 & Ierissos Gulf, Greece & $40^{\circ} 22^{\prime} 57.1^{\prime \prime} \mathrm{N}, 23^{\circ} 55^{\prime} 53.0^{\prime \prime} \mathrm{E}$ & In 2018 & SP & Photo 19 \\
\hline 20 & 1 & 0 & Protaras, Cyprus & $35^{\circ} 00^{\prime} 00.6^{\prime \prime} \mathrm{N}, 34^{\circ} 04^{\prime} 06.5^{\prime \prime} \mathrm{E}$ & $25 / 08 / 2018$ & $\mathrm{HG}$ & $\underline{\text { Photo } 20}$ \\
\hline 21 & 1 & 0 & Ormidia, Cyprus & $34^{\circ} 58^{\prime} 43.4^{\prime \prime} \mathrm{N}, 33^{\circ} 46^{\prime} 04.4^{\prime \prime} \mathrm{E}$ & $30 / 01 / 2018$ & HG & Photo 21 \\
\hline 22 & 1 & 5 & Zygi, Cyprus & $34^{\circ} 42^{\prime} 52.9^{\prime \prime} \mathrm{N}, 33^{\circ} 18^{\prime} 25.4^{\prime \prime} \mathrm{E}$ & $04 / 08 / 2018$ & S & $\underline{\text { Photo } 22}$ \\
\hline 23 & 1 & 2 & Thermaikos Gulf, Greece & $40^{\circ} 34^{\prime} 43.0^{\prime \prime} \mathrm{N}, 22^{\circ} 56^{\prime} 17.8^{\prime \prime} \mathrm{E}$ & $01 / 06 / 2018$ & LO & Photo 23 \\
\hline 24 & 1 & 0.1 & $\begin{array}{l}\text { Kiparrisiakos Gulf, } \\
\text { Greece }\end{array}$ & $37^{\circ} 39^{\prime} 15.9^{\prime \prime} \mathrm{N}, 21^{\circ} 19^{\prime} 30.9^{\prime \prime} \mathrm{E}$ & 01/08/2018 & LO & Photo 24 \\
\hline 25 & 1 & N/A & Thracian Sea, Greece & $40^{\circ} 56^{\prime} 27.5^{\prime \prime} \mathrm{N}, 25^{\circ} 19^{\prime} 58.4^{\prime \prime} \mathrm{E}$ & 08/10/2019 & SF & $\underline{\text { Photo } 25}$ \\
\hline 26 & 1 & 1 & Kastelorizo island, Greece & $36^{\circ} 09^{\prime} 01.0^{\prime \prime} \mathrm{N}, 29^{\circ} 35^{\prime} 27.0^{\prime \prime} \mathrm{E}$ & $13 / 09 / 2019$ & SF & - \\
\hline 27 & 4 & 0.3 & Rhodes island, Greece & $35^{\circ} 55^{\prime} 40.3^{\prime \prime} \mathrm{N}, 27^{\circ} 51^{\prime} 27.0^{\prime \prime} \mathrm{E}$ & $22 / 10 / 2019$ & SA & - \\
\hline
\end{tabular}


Figures

Fig. 1 Spatial distribution of the observations of the tripletail Lobotes surinamensis (Bloch, 1790) reported to the citizen-science project. Detailed information about each observation number is shown in Table 1

Fig. 2 Some of the reported specimens based on the photographic evidence provided by the citizen scientists to the project. Detailed information about each observation number is shown in Table 1

Conflict of Interest: The authors declare no conflict of interest. 


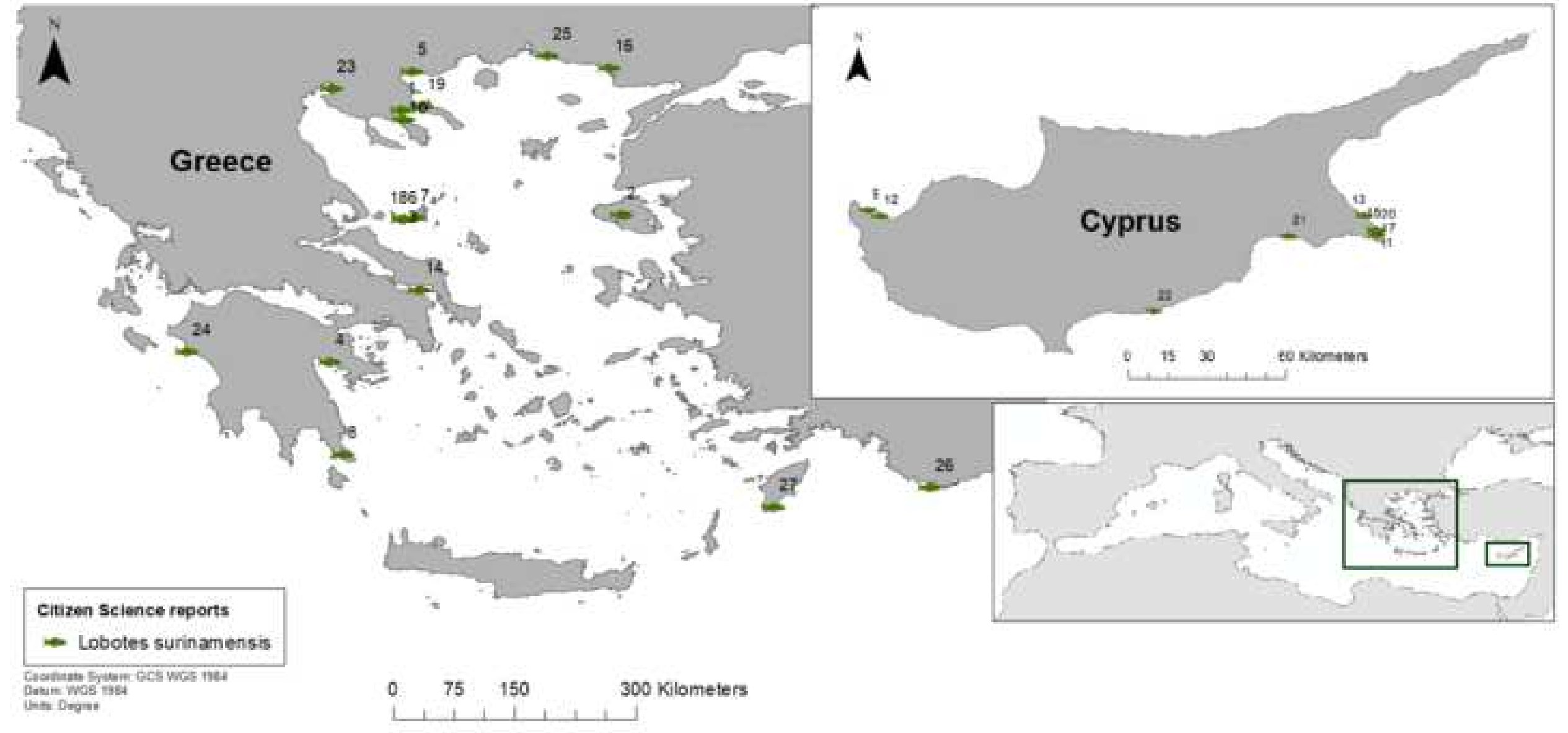


